\title{
A Study On The Implementation Of Wa- ter Resources Conservation Technology And Domestic Wastewater Management In the Building Design Of Dr. Heinz Frick House In Semarang And Turi House In Solo
}

\author{
Wuri Hamumpuni ${ }^{1}$ and Johanita Anggia \\ Rini $^{2}$ \\ ${ }^{1}$ Department of Architecture , Faculty of Civil Engineering and Planning, \\ Universitas Islam Indonesia, Yogyakarta \\ 2 Department of Architecture , Faculty of Civil Engineering and Planning, \\ Universitas Islam Indonesia, Yogyakarta
}

Article History

Received : 07 April 2017

Accepted : 24 May 2017

Published: 30 Oktober 2017

\begin{abstract}
The objective of this study is to identify water conservation technology and domestic wastewater management in relation to building design. Water sanitation and conservation aspects were examined based on three parameters such as table checklist of Water as an Ecological Factor for a Sustainable Campus Landscape method of DCBA Sustainable Housing in Indonesia and Greenship from Green Building Council Indonesia. Every parameter has benchmark that every building should attempt to fulfil as much as possible. This research used literature study, field survey, and interview with some relevant resource person to get relevant data based on related theories. The findings of the research found the values that indicate how far the implementation of water conservation technology and waste management in both research objects. Qualitative analysis is used to complete the three parameters of analysis and the quantity of water saving is also considered.
\end{abstract}

Keywords: building, water contamination, water conservation, waste water management, building design.

\section{Introduction}

Architecture as a discipline about building does not only designing building but it also considers the site environment that becomes the medium of ongoing development. The site that has been built should contribute some impacts to the surrounding environment. Thus, environmental factor in architecture is crucial to consider in order to keep the balance of ecosystem.

Correspondence: Wuri Hamumpuni

Department of Architecture , Faculty of Civil Engineering and Planning, Universitas Islam Indonesia, Yogyakarta. E-mail: whamumpuni@gmail.com
Yogyakarta is famous as tourism city for both domestic and foreign tourists. To accommodate the tourists, many public facilities are built such as hotel, restaurants, prayers place, mall, etc. One of the facilities that increase significantly is the hotel facility. The number of hotels rapid grows in number within 6 years period. In the year 2012, Yogyakarta built 15 hotels within one year (Sabda, 2015).

Meanwhile, Dr. Heinz Frick House in Semarang and Turi House in Solo had tried to implement simple system to reduce environmental damage by minimizing the use of clean water, maximizing waterrecycling system, and re-using rainwater and wastewater (Rinka, 2014). 
Five similar kinds of researches that have been done had different objectives. The first research conducted by Kusumarini (2007) aimed to compare the implementation of ecological architecture research (Rinka, 2016) focused more the saving planning and the third study (Febrianto, 2012) had more emphasis on identifying the implementation of Green Architecture in the dormitory of PGSD UNNES Students. The fourth research by Wahademaputra (2014) discussed the aspects that should be considered in designing building with sustainable water utilization concept. Finally, the fifth study from Amr (2015) aimed to define the list of landscape size related to water in campus based on best international practice and literatures.

\section{Research Objectives, Research Scope, and Limitation of the Prob- lems}

The goal of this research is to identify the implementation of water conservation system technology and domestic wastewater management in the building design of Dr. Heinz Frick in Semarang and Turi House in Solo through three parameters as follows:

1.Table of Parameters Checklist taken from the article entitled Water as an Ecological Factor for Sustainable Campus Landscape (Amr, 2015).

2.DCBA Method from research Larasati, Toward an Integral Approach of Sustainable Housing in Indonesia with an Analysis of Current Practices in Java. 2007.

3.Guidance from Greenship Existing Building \& Interior Space, for Greenship Water Conservation Category from Green Building Council Indonesia.

The scope of this research is the implementation of water conservation system, water storing system, water processing, water utilization, and the impacts towards building design.
This research is limited to three parameters because those three parameters could be combined into one to assess water conservation system in the building because the three parameters had different focus as follows:

Parameters as follows:

1. Table of Parameters Checklist (Amr, 2015): focuses on water conservation in the landscape elements.

2. DCBA Method from Larasati: focuses on simple water utilization in the building.

3. Guidance from Greenship Existing Building \& Interior Space, for Greenship Water Conservation Category: focuses more in the water utilization in the building interior and the impact towards the furniture in the building.

\section{Water Re-use and Water Manage- ment}

Water as ecological factor that covers $70 \%$ of the Earth has become global issues due to its scarcity. Thus, the consumption of water should get more attention. Sustainable water does not only mean preserving the water in the environmental site, but also integrating the system to achieve balance between water, soil, vegetation, and materials. The variety of balance in water utilization are also crucial to be considered (Calkins, 2012).

When the availability of water is higher than the demand, then the excess of water can be stored so it, make available when needed to make it available when needed. When the demand of water is higher than the water needed in the location should be lower to achieve balance. The number of water that will be stored is the highest percentage of monthly water need based on availability that is normally less than $100 \%$, or mostly around $75 \%$ to $90 \%$, (Calkins, 2012). Some types of storage are followings:

1. Surface storing include every low surface in the location that can save water.

2. Accumulating basin that include water tanks or container. 
3. Modifying water tank integrated with infiltration system and does not have large area.

This is specifically research about storing system, utilization, and management of water that influence architectural design of the building.

\section{Water conservation and Domestic Wastewater Management}

Besides the utilization of water conservation, domestic wastewater management also becomes the parameter of environmentally friendly building according to the regulation from the minister of environment number 8 year 2010 about Criteria and Certification of Environmentally Friendly Building Chapter Two, article 4. Ecofriendly building should at least have facilities, medium, and infrastructure of domestic wastewater of the building as follows:

1. Completing the building with domestic wastewater management system in the building for business and building with specific function.

2. Completing the building construction with domestic wastewater reutilization system in the building for business function and specific function.

The development of water saving technology should be enhanced by doing research and conducting preservation. In the architectural field, the management of domestic wastewater can be accommodated and implemented for architectural element for special function in the periodic building design.

\section{Greenship of Green Building Coun- cil Indonesia}

Green Building Council Indonesia is a nongovernment or not for profit institution that has full commitment towards community education in applying best environmental practice and to facilitate the transformation of sustainable global building industry. One of the programs from $\mathrm{GBCl}$ is to conduct Green Building Certification in Indonesia is based on the rating system, which contains some items of assessment aspect with certain point for each item.

$\mathrm{GBCl}$ is now in the process of draft arrangement from the rating system so that the name for the rating system in Greenship. Greenship is a rating system that can assess whether a building can be certified as green building or not based on six aspects. However, this research focused on the aspect of water conservation to assess whether the building has implemented technology system for water conservation and waste management implementation in architectural design that become research focus. Benchmark are based on the aspects of Water Conservation, such as Water Sub watering, Water Monitoring Control, Fresh Water Efficiency. Water Quality, Recycled Water, Potable Water, Deep Well Reduction, and Water Trap Efficiency (Green Building Council Indonesia, 2012).

\section{Research Methodology Type of Research}

The type of this research is descriptive research that describes that scheme of water resources conservation technology and domestic wastewater management in the building architectural design. In addition, this research also compared the most optimum technology based on Greenship for building construction and Greenship for inner room from the rating system of $\mathrm{GBCl}$, guidance table from Water as an Ecological Factor for Sustainable Campus Landscape and table of method guidance from DCBA.

\section{Variable Identification}

The objects of this research are two buildings that have implemented water conservation technology i.e. Dr. Heinz Frick house in Semarang and Turi House in Solo. The variables of this research are followings:

1. Independent Variable: water resources conservation system and domestic wastewater management and its imple- 
mentation in the design of building architecture.

2. Dependent Variable: Tools and network used for water resource conservation and domestic wastewater management.

\section{Data Collection Method}

The process of data collection can be done by conducting survey to see directly the water conservation process and domestic wastewater. The analysis about the conservation technology system and wastewater management is conducted based on Greenship for constructed building and Greenship for inner room based on rating system from $\mathrm{GBCl}$, guidance table from Water as an Ecological Factor for Sustainable Campus Landscape .

\section{Data Analysis}

Data analysis was conducted to process data obtained in this research by using literature study method. The researcher will present the data with detail explanation based on field survey both for the quantity and for quality aspect.

\section{Results and Discussion The House of Dr. Heinz Frick, Sema- rang}

The House of Dr. Heinz Frick in Semarang City became the subject of this research because it has implemented rainwater accumulator for the conservation of the available water resources. The management of rainwater in Dr. Heinz Frick has been well structured in which the water is directed to the storage that is close to the function as can be seen in Figure 1 in which the location of water accumulating basin is in the front part that can accessed easily for plants watering and the accumulating basin in the back part used for activities in the kitchen and for washing.

From the building schematic piece of Dr. Heinz Frick House in the Figure 2, we can see that the water accumulator is located in the lower room because the house has house on stilts. The accumulating basin can save water up to $17 \mathrm{~m} 3$ with estimated room size for about $3 \mathrm{~m} x$ $3 \mathrm{~m} \times 2 \mathrm{~m}$. This indicated that most the parts of in Dr. Heinz Frick house are a network of rainwater saving management.

Figure 1. Horizontal Scheme of Rainwater Processing in the House of Dr. Heinz Frick (Source: Prijatna, 2016, redrawn by the researcher).

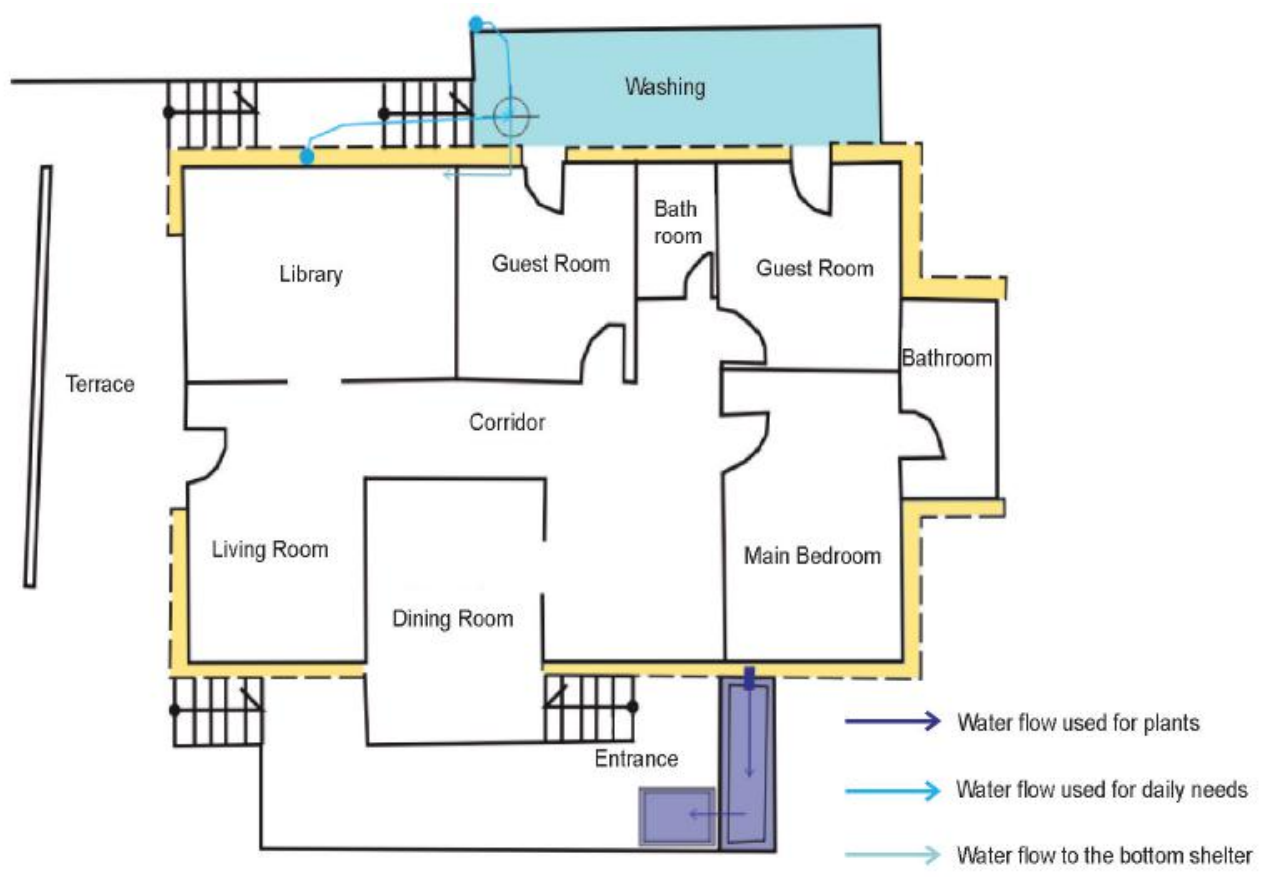


Figure 2. Vertical Schematic of Rain Water Management in the House of Dr. Heinz Frick

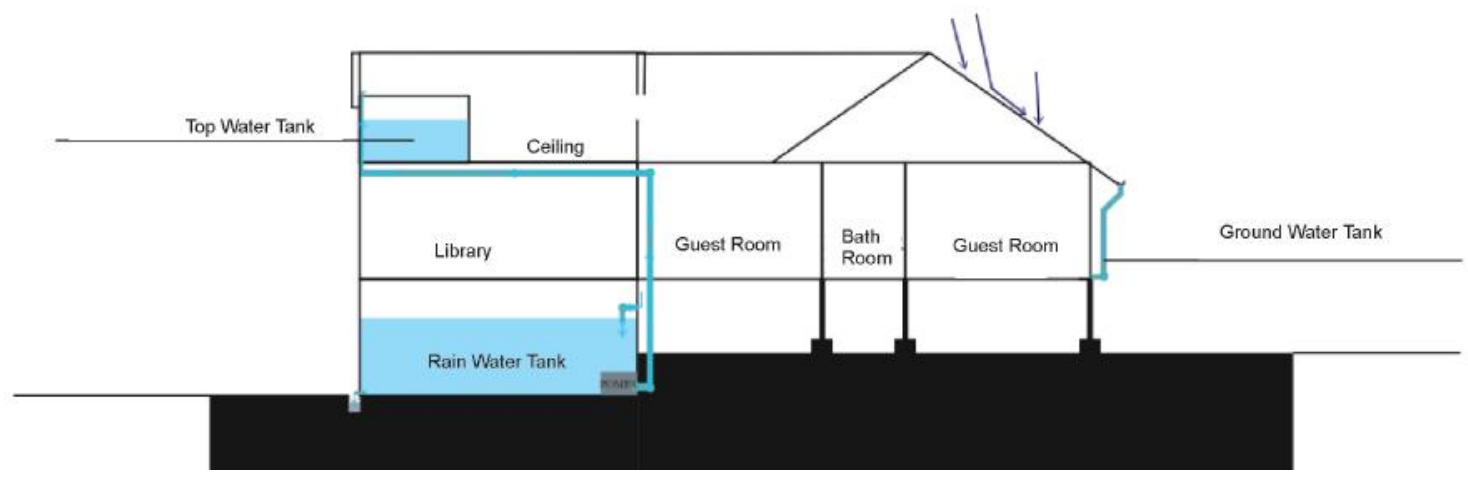

\section{House of Turi, Solo}

House of Turi is an inn with 18 rooms in Solo that implemented rainwater and wastewater management systems, which then purified with natural system and filtering. From the site plan schematic in Figure 3, as redrawn by the researcher, it can be seen that the position of conservation covers the whole building the filtering pond is located the public area that can be seen by the visitors. The pond has the functions both as water conservation and as beautiful sight for the visitors.

Figure 3. Site plan scematic of Turi House (Source: Google Maps that is redrawan by the researcher).
The filtering pond has the layers of river rock, gravel, sand, and palm fiber for maximum absorption to the ground and the water is already clean. The water that has been filtered 4 times then will be purified before it is used for some activities such as watering plants. The details can be seen in Figure 4 below:

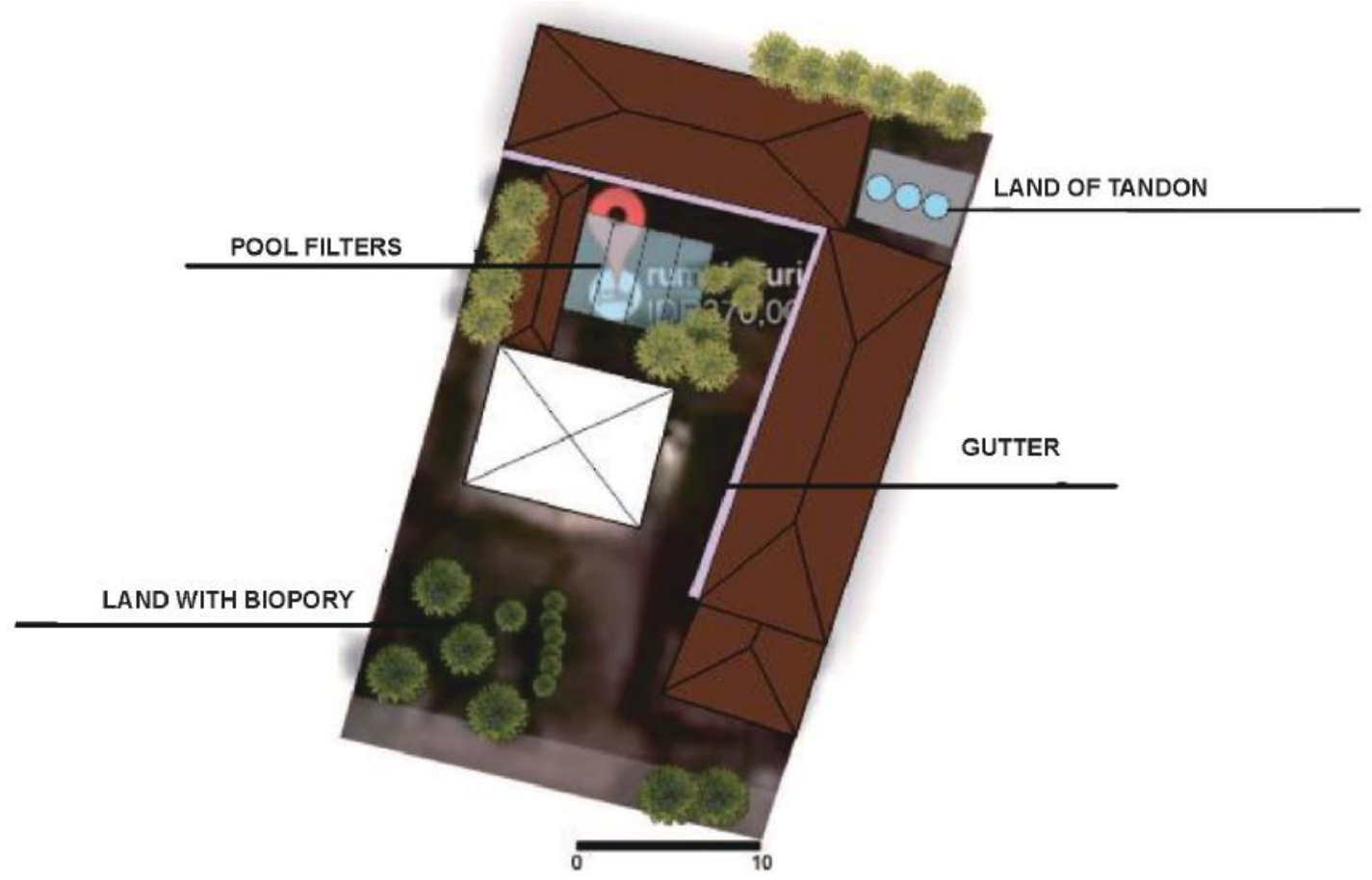


Figure 4 Schematic piece of Filtering Pong in House of Turi

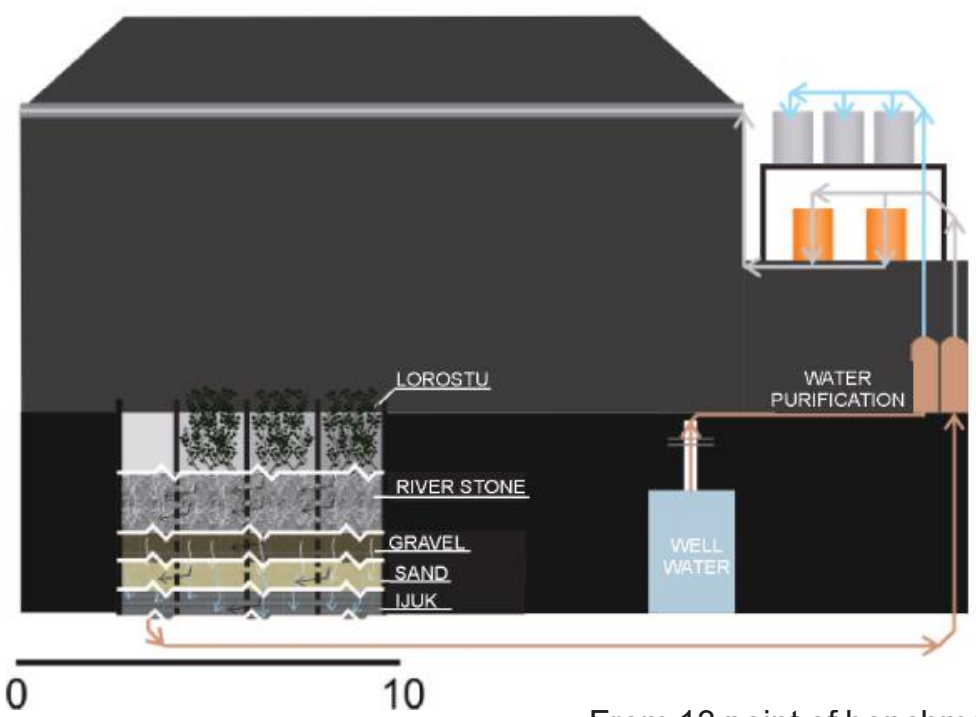

Evaluation :

1. Based on the Parameter Checklist table of Water as an Ecological Factor for Sustainable Campus Landscape.

Table 1 Checklist Table Parameter of Water as an Ecological Factor for Sustainable Campus Landscape (Amr, 2015)
From 13 point of benchmarks, the House of Dr. Heinz Frick has just met 7 benchmarks or $54 \%$ from the total benchmarks. The House of Dr. Heinz Frick has implemented the conservation of rainwater with water disposal in the site coming from the gutter directed to the accumulating basin. The accumulated rainwater is used for daily need such as for watering the plants.

\begin{tabular}{|l|l|l|}
\hline \multicolumn{1}{|c|}{ Water } & $\begin{array}{l}\text { Dr. } \\
\text { Heinz } \\
\text { Frick } \\
\text { House }\end{array}$ & $\begin{array}{l}\text { Rumah } \\
\text { Turi }\end{array}$ \\
\hline Reuse of wastewater onsite. & & \\
\hline $\begin{array}{l}\text { Promote groundwater recharge and maximize the pervious surfaces to permit the } \\
\text { water infiltration. }\end{array}$ & $\mathrm{v}$ & $\mathrm{v}$ \\
\hline Reuse of rainwater and run off. & $\mathrm{v}$ & $\mathrm{v}$ \\
\hline Application of strom water management. & $\mathrm{v}$ & $\mathrm{v}$ \\
\hline Reaching the point where the water supply is higher than the demand. & $\mathrm{v}$ & $\mathrm{v}$ \\
\hline Dispersing storm water system to decrease the over usage of soil. & $\mathrm{v}$ & $\mathrm{v}$ \\
\hline Provision of savety measures for interaction with the display water systems. & & \\
\hline Making use of site natural attributes that supports infiltration to reduce costs. & & $\mathrm{v}$ \\
\hline Treatment of harvested water before using for vegetation. & & $\mathrm{v}$ \\
\hline Isolating water storing systems of water harvesting to provide hygiene and safety. & $\mathrm{v}$ & $\mathrm{v}$ \\
\hline Growing native plants to decrease the water consumption. & & $\mathrm{v}$ \\
\hline $\begin{array}{l}\text { Maintenance of water delivery, distribution and irrigation to decrease any leak of } \\
\text { water. }\end{array}$ & & \\
\hline The percentage of stored water is relevant to the use of the building. & $\mathrm{v}$ & $\mathrm{v}$ \\
\hline $\begin{array}{l}\text { If graywater or wastewater is to be recycled for landscape irrigation, consider con- } \\
\text { ducting chemical tests to determine suitability for reuse on intended vegetation. }\end{array}$ & & \\
\hline
\end{tabular}


Meanwhile, The House of Turi has met 10 out of 13 benchmarks or around $77 \%$ from the total benchmark. The House of Turi has used bio-pore in particular spot on the open area using river rock, gravel, sand, and palm fiber so that the rainwater that goes underground stay clean. This indicated that House of Turi has maximized the absorption in the ground.

\section{Based on DCBA method.}

From DCBA method, the House of Dr. Heinz Frick has achieved slight increase of $56.2 \%$ by using rainwater for cooking, drinking, and plants watering. For the House of Turi, DCBA method has allowed the House to meet $87.5 \%$ of the ideal situation because the water in the site from well and rainwater has been purified.

3. Based on Greenship Existing Building \& Interior Space for the Category of Water Conservation according to Greenship of Green Building Council Indonesia.

Table 2. DCBA Method (Source: Larasati, 2007).

\begin{tabular}{|c|c|c|c|c|c|c|}
\hline Aspects & $\begin{array}{c}\text { Common } \\
\text { Usage }\end{array}$ & \begin{tabular}{|cc} 
C & Slightly \\
Improved
\end{tabular} & \begin{tabular}{|l|} 
B \\
Substantially \\
Improved
\end{tabular} & $\begin{array}{cc}\text { A } & \\
\text { Ideal } \\
\text { Situation }\end{array}$ & $\begin{array}{l}\text { Dr. } \\
\text { Heinz } \\
\text { Frick } \\
\text { House }\end{array}$ & $\begin{array}{l}\text { Rumah } \\
\text { Turi }\end{array}$ \\
\hline $\begin{array}{l}3 \\
\text { Water }\end{array}$ & $\begin{array}{l}\text { Direct disposal } \\
\text { systems }\end{array}$ & Water Saving Use & $\begin{array}{l}\text { Efficient } \\
\text { Water Use }\end{array}$ & $\begin{array}{l}\text { Self-Suppliying } \\
\text { Systems }\end{array}$ & C & B \\
\hline $\begin{array}{l}3-1 \\
\text { Re- } \\
\text { source }\end{array}$ & $\begin{array}{l}\text { Conventional (tap } \\
\text { water) stateowned } \\
\text { water company or } \\
\text { drilling own well }\end{array}$ & $\begin{array}{l}\text { Add collected rain- } \\
\text { water for house- } \\
\text { hold purpose other } \\
\text { than drinking/cook- } \\
\text { ing }\end{array}$ & $\begin{array}{l}\text { Add collected } \\
\text { and purifield } \\
\text { (soil/rain) wa- } \\
\text { ter }\end{array}$ & $\begin{array}{l}\text { Own water } \\
\text { well, added by } \\
\text { purified (soil/ } \\
\text { rain) water }\end{array}$ & C & A \\
\hline $\begin{array}{l}3-2 \\
\text { Waste }\end{array}$ & $\begin{array}{l}\text {-Trow waste wa- } \\
\text { ter directly to sew- } \\
\text { ers through water } \\
\text { draining pipes } \\
\text {-Let rainwater di- } \\
\text { rectly falls into sew- } \\
\text { ers through drain- } \\
\text { age pipes }\end{array}$ & $\begin{array}{l}\text { Directly re-using } \\
\text { grey water (e.g. } \\
\text { for watering plants/ } \\
\text { gardening, wash- } \\
\text { ing bikes/cars). }\end{array}$ & $\begin{array}{l}\text { Filtering grey } \\
\text { water for } \\
\text { hous e o old } \\
\text { purpos es, } \\
\text { other than } \\
\text { drink ing } / \\
\text { cooking }\end{array}$ & $\begin{array}{l}\text { Eliminating } \\
\text { waste water by } \\
\text { cutting out use } \\
\text { (i.e. dry toilet) }\end{array}$ & C & B \\
\hline $\begin{array}{l}\text { 3-2 } \\
\text { Drinking } \\
\text { Water }\end{array}$ & $\begin{array}{l}\text { No or difficult ac- } \\
\text { cess to drinking } \\
\text { water }\end{array}$ & $\begin{array}{l}\text { - Moderate access } \\
\text { to drinking water } \\
\text { (i.e. communal } \\
\text { pump) } \\
\text { - Conventional wa- } \\
\text { ter pipes and taps }\end{array}$ & $\begin{array}{l}\text { Efros } \\
\text { Easy access } \\
\text { to drinking } \\
\text { water (house- } \\
\text { hold pump) }\end{array}$ & $\begin{array}{l}\text { Also harvest } \\
\text { and purify rain- } \\
\text { water and soil } \\
\text { water up to } \\
\text { drinking quality }\end{array}$ & B & A \\
\hline
\end{tabular}


Table 3 Greenship Existing Building of Green Building Council Indonesia.

\begin{tabular}{|c|c|c|c|c|c|}
\hline \multicolumn{4}{|c|}{ WATER CONSERVATION-EXISTING BUILDING } & \multicolumn{2}{|c|}{ POINT } \\
\hline \multirow[t]{2}{*}{ WAC 1} & \multirow{2}{*}{$\begin{array}{l}\text { Water } \\
\text { Subme- } \\
\text { tering }\end{array}$} & & \multirow{2}{*}{$\begin{array}{l}\text { There is a sub-meter of water consumption on a } \\
\text { public area system, area commercial and building } \\
\text { utilities. }\end{array}$} & $\begin{array}{l}\text { Dr. Heinz } \\
\text { Frick House }\end{array}$ & $\begin{array}{l}\text { Rumah } \\
\text { Turi }\end{array}$ \\
\hline & & & & $0 / 1$ & $0 / 1$ \\
\hline WAC 2 & $\begin{array}{l}\text { Water } \\
\text { Moni- } \\
\text { toring } \\
\text { Control }\end{array}$ & & $\begin{array}{l}\text { The existence of standard procedures operation } \\
\text { and execution regarding maintenance and inspec- } \\
\text { tion of plumbing systems periodically to prevent } \\
\text { occurrebce of leakage and wate of water with } \\
\text { shows a deep water balance. Last } 6 \text { months for } \\
\text { initial certification. }\end{array}$ & $1 / 2$ & $2 / 2$ \\
\hline \multirow[t]{2}{*}{ WAC 3} & \multirow[t]{2}{*}{$\begin{array}{l}\text { Fresh } \\
\text { Water } \\
\text { Effi- } \\
\text { ciency }\end{array}$} & 1 & $\begin{array}{l}\text { For buildings with consumption water } 20 \% \text { above } \\
\text { SNI * every } 10 \% \text { decrease got } 1 \text { points until it } \\
\text { reaches the standard reference (SNI 03-7065- } \\
2005 \text { on Procedures of Implementation Plug } \\
\text { systems) with maximum } 2 \text { points. }\end{array}$ & \multirow[t]{2}{*}{$6 / 6$} & \multirow[t]{2}{*}{$5 / 6$} \\
\hline & & 2 & $\begin{array}{l}\text { If it meets point } 1 \text {, next every effort decreased wa- } \\
\text { ter consumption at } 3 \% \text {, of the reference standard } \\
\text { (SNI) gets } 1 \text { point. Maximum value is } 6 \text { point. }\end{array}$ & & \\
\hline WAC 4 & $\begin{array}{l}\text { Water } \\
\text { Quality }\end{array}$ & & $\begin{array}{l}\text { Shows evidence laboratory last } 6 \text { months of the } \\
\text { primary source water in accordance with the } \\
\text { criteria of clean water at least once in } 6 \text { month for } \\
\text { initial certification. }\end{array}$ & $0 / 1$ & $0 / 1$ \\
\hline WAC 5 & $\begin{array}{l}\text { Water } \\
\text { Quality }\end{array}$ & & $\begin{array}{l}\text { Using water cle with a capacity of enough for } \\
\text { make needs up water cooling tower. This Bench- } \\
\text { mark applies only for buildings that use cooling } \\
\text { tower on the systems its cooler. }\end{array}$ & - & - \\
\hline WAC 6 & $\begin{array}{l}\text { Portable } \\
\text { Water }\end{array}$ & & $\begin{array}{l}\text { Using filtration systems which produces drinking } \\
\text { water which is in accordance with Permenkes No. } \\
492 \text { of } 2010 \text { about Water Quality Requirements } \\
\text { Drink * at least in every kitchen or pantry. }\end{array}$ & $0 / 1$ & $0 / 1$ \\
\hline \multirow[t]{3}{*}{ WAC 7} & \multirow{3}{*}{$\begin{array}{l}\text { Deep } \\
\text { Well } \\
\text { Reduc- } \\
\text { tion }\end{array}$} & $1 \mathrm{~A}$ & $\begin{array}{l}\text { Consumption of water using deep well maximum } \\
20 \% \text { of consumpton water as awhole. }\end{array}$ & \multirow{3}{*}{$1 / 2$} & \multirow{3}{*}{$1 / 2$} \\
\hline & & & or & & \\
\hline & & 1B & $\begin{array}{l}\text { Consumption of water using deep well maximum } \\
10 \% \text { of consumption water as a whole. }\end{array}$ & & \\
\hline \multirow[t]{3}{*}{ WAC 8} & \multirow{3}{*}{$\begin{array}{l}\text { Water } \\
\text { Tap Ef- } \\
\text { ficiency }\end{array}$} & $1 \mathrm{~A}$ & $\begin{array}{l}50 \% \text { of the total water tap unit on the public use } \\
\text { area auto stop feature. }\end{array}$ & \multirow{3}{*}{$0 / 2$} & \multirow{3}{*}{$0 / 2$} \\
\hline & & & or & & \\
\hline & & $1 \mathrm{~B}$ & $\begin{array}{l}80 \% \text { of the total water tap unit on the public use } \\
\text { area auto stop feature. }\end{array}$ & & \\
\hline
\end{tabular}

$\mathrm{GBCl}$ Greenship Parameter used in this research is Greenship Existing Building and Interior Space. The House of Dr. Heinz Frick evaluated with Greenship Existing Building dan Interior Space achieved 9 points out of 25 points or equal to $36 \%$ for those implementing Water Conservation based on the standard of $\mathrm{GBCl}$. With four members of the family, the system In Dr. Heinz House has efficiently saved water use up to $25 \%$, as can be seen in the following calculation:
It is known that:

1. The standard of water use in a household according to SNI 03-0765-2005 about The Procedure of Plumbing System is $120 \mathrm{~L} /$ day / resident $x 4=480 \mathrm{~L} /$ day.

2. It is assumed that the water use is based on the parameter of water use in one day, i.e. $75 \mathrm{~L}$ /day/resident that is equal to 20 gallons. Each gallon consists of $3.7 \mathrm{~L}$ (Admin, 2014), so that $75 \mathrm{~L} \times 4=300 \mathrm{~L} /$ day. 
The calculation is:

1. $300 / 400 \times 100=62.5 \%$

2. $(480-300) / 480 \times 100=37.5 \%$

3. $62.5 \%-37.4 \%=25 \%>18 \%$, Thus, it can be concluded that the House of Dr. Heinz Frick has reduced the use of water up to $25 \%$ exceeding the standard of Greenship Existing Building of Green Building Council Indonesia in which every $3 \%$ of water use will get 1 point and with maximum 6 points that is equal to $18 \%$.

Meanwhile, the House of Turi based on $\mathrm{GBCl}$ Greenship got 10 points out of 25 that is equal to $40 \%$ of benchmarks from Water Conservation Greenship GBCl for building construction. The calculation of water efficiency from Greenship Existing Building of Green Building Council Indonesia can be seen as follows:

1.The standard of water use for Hotels or Inn according to SNI 03-7065-2005 about The Procedure of Plumbing System is $150 \mathrm{~L} / \mathrm{day} / \mathrm{bed}$.

2.Based on the interview, the water use in one day is $50 \mathrm{~L} /$ day/person, which is equal to 13.5 gallons where one gallon consists of 3.7 L (Admin, 2014).

Table 4 Greenship Interior Space of Green Building Council Indonesia
It can be calculated that:

1. $100 / 150 \times 100=66,6 \%$

2. $(150-50) / 100 \times 100=50 \%$

3. $66.6 \%-50 \%=16.6 \%<18 \%$,

4. Thus, it can be concluded that The House of Turi has been able to reduce water use up to $16.6 \%$ although it has not exceeded the standard from Greenship Existing Building of Green Building Council Indonesia where every $3 \%$ of water use reduce will get 1 point with maximum 6 points or equal to $18 \%$.

From the Greenship Interior Space, the House of Dr. Heinz Frick has accommodated the parameters because the House of Dr. Heinz Frick has not implemented fixture with water disposal below the standard.

In addition, the water spending network has not implemented submetering to see how much water has been consumed. Whereas, the House of Turi has accommodated this but it has not got sub metering to measure the number of water use. Since the processed water in Turi House has been purified, routine clinical test is needed to see the content of the water before being consumed.

\begin{tabular}{|c|c|c|c|c|c|}
\hline \multicolumn{4}{|c|}{ WATER CONSERVATION-INTERIOR SPACE } & \multicolumn{2}{|c|}{ POINT } \\
\hline \multirow[t]{3}{*}{ WAC 1} & \multirow[t]{3}{*}{$\begin{array}{l}\text { Water } \\
\text { Fixture }\end{array}$} & $1 \mathrm{~A}$ & $\begin{array}{l}\text { Minimum } 75 \% \text { of water fixtures in the tenant area to have a } \\
\text { maximum output capacity below standard according to the } \\
\text { table in attacment. }\end{array}$ & $\begin{array}{l}\text { Dr. } \\
\text { Heinz } \\
\text { Frick } \\
\text { House }\end{array}$ & $\begin{array}{l}\text { Rumah } \\
\text { Turi }\end{array}$ \\
\hline & & & or & \multirow[b]{2}{*}{$0 / 4$} & \multirow[b]{2}{*}{$0 / 4$} \\
\hline & & $1 \mathrm{~B}$ & $\begin{array}{l}\text { All of water fixtures in the tenant area to have a maximum } \\
\text { output capacity below standard according to the table in } \\
\text { attachment. }\end{array}$ & & \\
\hline \multirow[t]{2}{*}{ WAC 2} & \multirow{2}{*}{$\begin{array}{l}\text { Water } \\
\text { Use } \\
\text { Moni- } \\
\text { toring }\end{array}$} & 1 & $\begin{array}{l}\text { The availability of water metering within the tenant aea, } \\
\text { so as the management will have the information of water } \\
\text { consumption level. }\end{array}$ & $0 / 2$ & $0 / 2$ \\
\hline & & 2 & $\begin{array}{l}\text { The availability of monitoring and controlling systems } \\
\text { including periodic inspection of plumbing system to prevent } \\
\text { leakage and wastage of water by showing the water by } \\
\text { showing the water consumption. }\end{array}$ & $1 / 2$ & $1 / 2$ \\
\hline WAC 3 & $\begin{array}{l}\text { Por- } \\
\text { table } \\
\text { Water }\end{array}$ & & $\begin{array}{l}\text { Provide drinking water treatment with water purification pro- } \\
\text { cess, to meet employees' drinking water needs within the } \\
\text { tenant area, in accordance with Minister of health Decree } \\
\text { No. } 492 / 2010 \text { od Drinking Water Quality Requirements. }\end{array}$ & $0 / 2$ & $1 / 2$ \\
\hline
\end{tabular}


The House of Turi based on the GBC Greenship got 10 out of total 25 points that is equal to $40 \%$ of benchmarks in Water Conservation Greenship $\mathrm{GBCl}$ for construction by making water efficiency up to $16.6 \%$.

From the Greenship Interior Space, the interior space of Dr. Heinz Frick House has been accommodating. This is because the house of Dr. Heinz Frick has not implemented fixture that has water disposal below the standard.

In addition, the water spending network has not used sub metering to identify the number of water used. However, the activity in the house has been accommodating.

The weakness of Turi House is lacking of submetering to see how much water has been consumed. Since the processed water in Turi House has been purified, routine clinical test is needed to see the content of the water before being consumed.

\section{Discussion}

The benchmarks in table 3 have the same goal to save surface water for daily needs.

From the table checklist of Water as an Ecological Factor for Sustainable Campus Landscape (Amr, 2015), it can be seen that the parameter has more focus on the water conservation system air in the landscape. It sees how the rainwater supposed to fall in the surfaces that will help the water to enter the ground and provide new water resources, how is supply of water in the site, and how is the water disposal in the site.

According to checklist table from Water as an Ecological Factor for Sustainable Campus Landscape (Amr, 2015), safe points should be determined so that the network of water conservation management is safe for the visitors and it should be isolated well. The benchmarks of plants watering are needed to reduce plants watering in the dry season.
However, not all parameters can be measured quantitatively for some points that have been achieved by a building in completing water conservation system. For example, the benchmark for safety values has met the need of system isolation. However, it requires specific criteria in closed space such as what implemented in the House of Dr. Heinz Frick. The isolation could be in the open air covered by spreading plants or steel frame to get point in which isolation will be better from the parameters of water conservation principles.

Based on the evaluation using table checklist from water, Turi House has a more advanced water conservation system compared to the House of Dr. Heinz Frick. It is because the system in Turi House has the strength from the aspect of landscape that can add the aesthetics while the House of Dr. Heinz Frick focused more on the use of building and daily needs.

The DCBA method determined the water management principles by focusing on the system within the building especially on the water resource, water disposal, and water processing and obtaining. DCBA method has determined the benchmark for ideal situation.

The parameters include early stages up to the final phases such as water resource, water processing, water obtaining, etc. However, there has been no detail explanation or benchmark for disposal water, wastewater, and rainwater. The disposal of rainwater or wastewater will produce different situation.

DCBA Method has provided water conservation parameters starting from the water resources. Thus, it is necessary to see a building with water conservation concept by considering the water resources used in the building to get rough evaluation whether the building has independently used the water resources.

From the evaluation with DCBA method, Turi House has reached $87.5 \%$ of ideal situation because most of the conservation system in 
the house has fulfilled the ideal situation criteria such as filtered well water and processed water while the House of Dr. Heinz Frick has not filtered processed water.

Although DCBA method focused more on the building system, this method has not been holistic by suing fixture so that parameter of principles for water conservation system technology and domestic wastewater management in the building design can be completed with Greenship Green Building Council Indonesia.

The benchmark of Greenship Existing Building has determined the objective by using the parameter. Thus, the points can be calculated quantitatively and the success of a building in implementing system technology of water conservation and domestic wastewater management in the building design can be measured. The benchmarks have been completed and details compared to DCBA.

Greenship Interior Space also completes DCBA method from the aspect of water conservation in the interior space. From the evaluation of Greenship, Turi House is $4 \%$ stronger because it is easier to access the maintenance system for handling trouble and control because there is special technician for the maintenance while the one in the House of Dr. Heinz Frick is simpler. Thus, it is necessary for a construction to have the aesthetics of the building and the system implemented in the construction that increase the aesthetics as the house of Turi has started to implement and achieve.

However, the lack of implementation on system technology of water conservation and domestic wastewater management in the building design, make all parameters seems can be implemented in every building with its own function. In this research, the House of Dr. Heinz Frick that functions as residence and Turi House that functions as an inn has different complexities. Thus, different parameter will be needed as the standard of water use for house and hotel is different.
Therefore, further research can discuss about the making of models in implementing system technology of water conservation and domestic wastewater management in the building design based on the function of the building.

\section{Conclusion}

Table 5 Greenship Interior Space of Green Building

\begin{tabular}{|l|c|c|}
\hline \multicolumn{1}{|c|}{ Benchmark } & $\begin{array}{c}\text { Dr. Heinz } \\
\text { Frick } \\
\text { House }\end{array}$ & Rumah Turi \\
\hline $\begin{array}{l}\text { Water as an Ecological } \\
\text { Factor For Sustainable } \\
\text { Campus Landscape } \\
\text { (Journal of Procedia } \\
\text { Social and Behavioral } \\
\text { Sciences) }\end{array}$ & $54 \%$ & $77 \%$ \\
\hline $\begin{array}{l}\text { Metode DCBA. IARA- } \\
\text { SATI, Dwinita M,A. } \\
2007 \text { 56,2\% }\end{array}$ & $87,5 \%$ \\
\hline $\begin{array}{l}\text { Greenship of Green } \\
\text { Building Council In- } \\
\text { donesia-Greenship } \\
\text { Existing Building and } \\
\text { Greenship Interior } \\
\text { Space }\end{array}$ & & \\
\hline
\end{tabular}

From the analysis, it can be concluded that the research on system technology of water conservation and domestic wastewater management in the building design towards the research objects are still not optimal. This research uses two different objects with different functions because it is difficult to find research object about system technology of water conservation and domestic wastewater management in the building design.

From the analysis, it is found that Turi has higher percentage than the House of Dr. Heinz Frick. It is because the system in Turi House is more sophisticated than the one used in the House of Dr. Heinz Frick. The reason is the Turi House besides rainwater, the house also process bath wastewater from the bathroom while Dr. Heinz Frick house only process rainwater.

Thus, the implementation of technology for water conservation in the building design needs 
careful planning by considering the processing steps to make the utility system in the building also has valuable aesthetics by considering the building function to give different variation that will affect the building architectural design.

\section{Reference}

Amr, Ahmed.I, et al. (2015). Water as an Ecological Factor for a Sustainable Campus Landscape Journal of Procedia Social and Behavioral Science. Accessed on 15 March 2015. Retrieved from http:// www.sciencedirect.com/science/article/ pii/S1877042815062072.

Calkins, M. (2012). The Sustainable Sites Handbook: A Complete Guide to the Principles, Strategies, and Best Practices for Sustainable Landscapes. John Wiley \& Sons, Inc. Hoboken, New Jersey.

Febrianto, Rahmat. (2012). Kajian Penerapan Konsep Green Architecture Oleh Konsultan Perencana Di Kota Semarang (Studi Kasus Gedung Asrama Mahasiswa PGSD Unnes Oleh Pt. Widha). Accessed on 8 January 2016. Retrieved from http://journal.unnes.ac.id/sju/index. php scaffoldin.

Green Building Council Indonesia. Greenship Rating Tools Untuk Gedung Terbangun. Januari 2011 dan Untuk Ruang Dalam April 2012. Accessed on 28 April 2016. Retrieved from www.gbcindonesia.org.

Kusumarini, Yusita, dkk. Kajian Terapan EkoInterior pada Bangunan Berwawasan Lingkungan Rumah Dr. Heinz Frick di Semarang; Kantor PPLH di Mojokerto; Perkantoran Graha Wonokoyo di Surabaya. 21 Agustus 2007. Accessed on 8 January 2016. Retrieved from http:// jounals.itb.ac.id/index.php/jvad/article/ download/663/382.
Larasati, Dwinita M, A. (2007). Towards an Integral Approach of Sustainable Housing in Indonesia With An Analysis of Current Practices In Java. Accessed on 16 March 2016. Retrieved from https:// repository.tudelft.nl/islandora/object/ uuid\%3Ad9e07749-9bcb-4da6-beb2e78823eaebae.

Menteri Negara Lingkungan Hidup. Peraturan Menteri Negara Lingkungan Hidup No. 08 Tahun 2010 Tentang Kriteria dan Sertifikasi Bangunan Ramah Lingkungan. (2010). Accessed on December 2015. Retrieved from hukum.unsrat. ac.id/lh/menlh2010_8.pdf.

Prijatna, M. Donny M. (2016). Horizontal Scheme of Rainwater Processing in The House of Dr. Heinz Frick.

Rinka, Yafina Dhea, dkk. (2014). Perencanaan Sistem Plambing Air Limbah dengan Penerapan Konsep Green Building pada Gedung Panghegar Resort Dago Golf Hotel \& Spa. Accessed on 8 January 2016. Retrieved from http://jurnalonline. itenas.ac.id/index.php/lingkungan/article/view/515.

Sabda. 2015. Fakta Perkembangan Hotel di Yogyakarta yang Mengejutkan. Accessed on 7 January 2016. bersabda. com. 